\title{
Ernest Cushing Richardson 1860-1939
}

This article highlights the career of E. C. Richardson, and includes commentary relating to the wealth and diversity of his contributions to the field of American librarianship.

E.

C. Ruchardson was born in Woburn, Massachusetts on February 9, 1860, being one of four children in a family of modest income. He graduated from Woburn High School in 1876. His purpose in going to college was to prepare himself for the ministry. Amherst College offered him a part-time job in the library and since he had to have a source of additional support for his education, Amherst became his choice of college.

At Amherst College, Melvil Dewey had graduated in 1874 and had become the librarian of the college upon his graduation until 1876. Richardson's first year at Amherst was Dewey's last year as librarian, and one would like to believe that freshman Richardson, as parttime worker in the library, would come in contact with Dewey. This was not the case. Melvil Dewey's assistant, W. S. Biscoe, succeeded him as librarian and Richardson received his official training under his supervision. In his senior year, Richardson served as assistant librarian. This position did not keep him at Amherst. He left for Hartford, Connecticut to study for the ministry at the Hartford

Mr. Hadidian is librarian at the Clifford E. Barbour library, Pittsburgh Theological Seminary, Pittsburgh, Pennsylvania.
Theological Seminary. Again, his choice of the seminary was based upon the opportunity offered there for part-time work in the library. Dr. Chester David Hartranft, Jr., the librarian of the institution, was one of the charter members and founders of the American Library Association, and Richardson worked under him during the three years of his theological education. A graduate of the seminary, Mr. Henry Hopkins Kelsey, class of 1879, was appointed as assistant librarian to Dr. Hartranft to relieve him from routine work; due to the fact that both men were also involved in teaching responsibilities, however, the library was essentially left in the hands of E. C. Richardson, who became assistant librarian in 1882 during his senior year (compare his same position at Amherst), and librarian in 1884, when Dr. Hartranft resigned only to become the president of the institution some four years later.

In a letter dated April 4, 1885, Richardson had this to say about the image of a librarian in an academic theological institution:

During my college course, I used to hear a good deal of talk among librarians, to the effect that the old conception of librarianship had passed away. . . . It was considered that the appointment of Winsor at 
Harvard was a practical culmination and establishing of the idea that librarianship was a learned profession and the librarian in a literary institution, a professor. . . . In thinking, therefore of the position of "librarian" I had hardly thought of it except as ultimately a regular constituent of the faculty. With that conception I have been working and trying to fit myself for the position. I believe that in view of his large opportunities for influencing the opinions of the students .... and that his opinions are looked on by those without as representing the Seminary, the librarian should be in direct relation with those who form the policy, whether doctrinal, pedagogical or prudential of the Seminary. The librarian, as I understand it, would stand in much the same relation to an institution as the regular professors. His pedagogical methods are different and less systematic but important, his literary relation to the Bibliography, Literary History and Encyclopedia of the Church, the same as that of the Prof. to his department, and his responsibilities not parallel to, but demanding an ideal of attainments similar in kind to those of the other departments and exceeded in extent by none. A theological librarian should at the lowest aim at a thorough knowledge of Theological Encyclopedia, Literary History, and Bibliography, some considerable knowledge of Palaeography, a knowledge of at least ten or a dozen languages, besides the technical matters of library science, collating, keeping stock, which involve a good deal of study of typography, art of binding or engraving, etc., etc., etc. ${ }^{1}$

E. C. Richardson remained in Hartford until 1890, when he left for Princeton as assistant librarian and later, librarian, until his retirement in 1925. His early years at Hartford seemed to indicate that as a librarian he did not receive either verbal recognition of his contribution to scholarly research, or adequate financial remuneration for the work performed. In his letter to the prudential committee dated June 25, 1885, he wrote,

To the best performance, I gave up all teaching during term time and other opportunities for private work at a cash loss very modestly estimated at $\$ 1,000$ and devoted many more hours a day to my work than any other theological librarian, almost any librarian in the country, worked voluntarily through vacations and neglected no opportunity or pains or expense to improve myself and my profession. Your misconception must be from a misconception of the nature and requirements of the profession.

A crisis, small or great, brings out the worst and the best in an individual's thoughts. The fact that the institution did not give the rank of a professor to the librarian prompted Richardson to write an eighteen-page letter to the faculty, dated April 13, 1886. "I am anxious to have the right to the title 'professor' but not so much for the honor' or 'position' socially, in itself considered. It is to be sure, humiliating to occupy a position which is popularly looked on as one of accepted inferiority, but it is good discipline in humility, which I need. . . . But the fact has a practical bearing too. The position has been publicly construed as well as popularly regarded as less than that of Associate Professor." The letter (page 11) is resumed on April 21: "Since writing the above I have had a visit from a gentlemen connected with the Brooklyn Library. Not long since, as you know, I had a letter from Mr. Dewey, Librarian of Columbia College and secretary of the Library Association, asking if I would accept an election to the Brooklyn Library. . . . The two other names considered were those of Justin Winsor of Harvard College and Mr. Cutter of the Boston Athenaeum." The salary of E. C. Richardson was \$1,500; Mr. Winsor was receiving $\$ 4,500$ and $\mathrm{Mr}$. Cutter, $\$ 3,500$. Brooklyn Library would not offer less than $\$ 3,500$, and would perhaps offer more than $\$ 4,500$ in order to bring $\mathrm{Mr}$. Winsor to Brooklyn. Richardson writes in the same letter: "I told him that the money had little weight. I gave him some reasons-especially my decided theological and religious connections- 
why I should not be on the whole the man for them. . . ." Richardson's rank was raised to associate professor in May 1888 , and this was perhaps due to the fact that Washington and Jefferson College was to confer on him an honorary Ph.D. degree, primarily for his contribution in preparing Bibliographical Synopsis of the literature relating to the works included in The Ante Nicene Fathers published in Buffalo by the Christian Literature Company in 1887. His leaving Hartford for Princeton in 1890 was explained in a letter dated April 1, 1894, when he wrote to Dr. Hartranft: "Do you think there is likely to be anything in the plan for my return to Hartford which you have hinted at once or twice. ... I left Hartford under the pressure of a financial need which no longer exists. ..."For in 1891 he married Grace Duncan Ely, and she brought a modest amount of wealth into the family which "allowed him the freedom of as many as seventeen trips to Europe for travel, professional meetings, study and book purchase." ${ }^{2}$ The Princeton years were his most productive period. His first massive work was on Periodical Articles on Religion, 1890-1899, in two volumes. (The first, a subject index, and the second, an author index published in 1907.) Other works better known in college and university libraries are the following:

Classification, Theoretical and Practical (New York: Scribner's, 1910), and two additional editions in 1912 and 1931; Beginnings of Libraries (Princeton and London: Princeton University Press and Oxford University Press, 1914), Biblical Libraries (Princeton and London: Princeton University Press and Oxford University Press, 1914). Some Old Egyptian Libraries (New York: Scribner's, 1911); Some Aspects of Cooperative Cataloguing (New York: H. W. Wilson Co., 1934); Some Aspects of International Library Cooperation (Yardley, Pa.: G. T. Vook and Son, 1928).
On March 15, 1935, Richardson read a paper on "The Future of Union Catalogs and of Cooperative Selection and Purchase" at a meeting of the American Library Institute in Atlantic City. What is significant in this paper is perhaps the final paragraph where Richardson states the following: "In view of the statement made in behalf of A.L.A. that, since less than eight percent of the A.L.A. membership is directly interested in the problems of the libraries of learning, it can do nothing to help solve them, it might seem to the members of this Institute which selects its membership from the librarians most interested in intellectual research and production rather than in administration that the duty of keeping up the burden of the research aspect of library management is thrust upon this body which is ostensibly one hundred percent interested in the problems of intellectual cooperation." 3 One cannot help but remind librarians of this generation of the distinction made by Richardson between administrative pursuits and scholarly and intellectual research in librarianship. His works are good examples of scholarly and intellectual research which he did not restrict to the United States. In May of the same year, 1935, Richardson read a paper at the Second International Congress of Libraries and of Bibliography in Madrid, Spain. He began his paper as follows:

“'To skin a deer,' says Bracton, 'first catch your deer.' 'To cook a hare,' adds Mrs. Glasse in her famous cookbook, 'first catch your hare.' It is the same with books. Bacon says that some books are to be tasted, some to be swallowed, a few to be chewed or digested, but to taste, chew, swallow, digest, catalogue, borrow, visit, copy, buy or steal a book, you must first find your book. . . . The task of libraries is to get together recorded ideas for the use of synthetic thinkers." ${ }^{4}$ In his doctoral dissertation, Lewis C. Branscomb, Jr., writes, "Ernest 
Cushing Richardson lived ahead of his day. His zeal and tireless efforts-in the area of cooperative selection of library materials, acquisition, cataloging and compilation of union catalogs, attained, in his own mind, distressingly limited realization." 5 The Librarian of Congress paid tribute to Richardson's contribution in these words, "The Union Catalog, although many shared in its building, is in special, the effective realization of the dream of Dr. Ernest Cushing Richardson. . . . Long before Dr. Richardson came to Washington ... . he had caught the vision of the service to scholarship that could be rendered by a cooperative bibliographical undertaking such as the Union Catalogue in its present form...."6 This bibliographic project was known as Project B. It was defined "as a task of increasing the bibliographical apparatus of the Library of Congress and more specifically the extension of the union catalogue of printed books and the catalogue of special collection." 7 Upon conclusion of the project in 1932, when it was turned over to Library of Congress staff, Branscomb states "Original goal of $6,000,000$ titles located for use [had been] reached and surpassed." 8 "The primary material as turned back to the Library of Congress consisted of: 1 . Union cata$\log$ of printed books in American Libraries. 2. A supplement union catalog of printed books in foreign libraries. 3 . A union catalog of special collections in American Libraries. 4. A supplement union catalog of special collections in foreign libraries. 5. A union list of world manuscripts."

One may summarize his other contributions by brief phrases: (1) "Title-a bar" printing of card catalogs and catalogs of books; (2) Regarding classification, he believed that the cataloger should blend theory with practicality, and in case of conflict, the practical should prevail. For him, classification was the highest function of the librarian's art, and it was an art, not a science; (3)
He believed in cooperative selection, cooperative purchasing, and cooperative cataloging. Full cataloging he considered "the curse of bibliographic cataloging." It is worth noting in this connection a very unusual meeting on the Princeton campus when as a result of Richardson's efforts, Grover Cleveland, Woodrow Wilson, John L. Cadwalader, and John S. Billings of the New York Public Library came together and "spent a long and serious afternoon studying the problems of the university library and chiefly the problem of encouraging cooperative cataloging by the use of printed cards. It was an impressive spectacle to a librarian to see an ex-president of the United States taking as earnest a responsibility in a matter of technical library cooperation as he did in his public dutiesand his unsparing pains in these is a part of history." 10 Branscomb comments with these words, "Seldom have library problems been pondered by such distinguished and able gentlemen."11 In 1925, Richardson became the Honorary Consultant in Bibliography and Research at the Library of Congress, and it was during this period that his projects listed above were accomplished. He retired to his Old Lyme home in Connecticut in 1936, and died there at the age of 79 in 1939. Thus came to an end the life of a librarian whose contribution truly fits the words spoken in 1780 by the Abbe des Housayes, librarian of the Sorbonne, "A librarian truly worthy of the name, should, if I may be permitted the expression, have explored in advance every region of the empire of letters, to enable him afterwards to serve as a faithful guide to all who may desire to survey it and though it is by no means my intention to give the preference above all other sciences to the science of bibliography . . . it will be nevertheless be permitted me to consider the science as the forerunner of all the others as their guide who is to light them with his torch. ..." ${ }^{12}$ 


\section{REFERENCES}

1. The letters of E. C. Richardson are deposited in the Archives Room of Case Memorial Library of the Hartford Seminary Foundation in Hartford, Connecticut.

2. Ruth Currie, "Ernest Cushing Richardson," an unpublished paper written in 1966 at the University of North Carolina School of Library Science, Chapel Hill, N.C., p.4-5.

3., 4. From a privately published source deposited at the Archives Room of Case Memorial Library.

5. Lewis C. Branscomb, Jr., A Bio-Bibliographical Study of Ernest Cushing Richardson, 1860-1939, University of Chicago,
1954 (microfilm), p.54.

6. Ibid.

7. Ibid., p.50.

8. Ibid., p.52.

9. Ibid., p.53.

10. E. G. Richardson, "The University Library in Its Cooperative Aspect," School and Society 32:218 (1930).

11. Pioneering Leaders in Librarianship; ed. by Emily Miller Danton (Chicago: American Library Association, 1953), p.149.

12. John L. Thornton, Classics of Librarianship (London: The Library Association, 1957), p.27-28. 